\title{
Estimating Time-Varying Capital Market Integration In The EMU
}

Usha R. Mittoo, University of Manitoba, Canada

Sergiy Rakhmayil, Ryerson University, Canada

\begin{abstract}
This paper analyzes the effect of the European monetary unification and economic liberalization in a sample of three EMU (France, Germany, Netherlands) and two non-EMU (U.K. and Switzerland) countries, as well as the European market index and a currency index, using data from March 1984 to November 2002. We utilize a multivariate GARCH framework and estimate jointly all parameters in the model. The study reveals that financial markets in Europe followed a gradual integration process. We also find that the Euro countries generally display higher degrees of market integration compared to the non-Euro countries in our sample.
\end{abstract}

Keywords: Market integration, capital market, International Asset Pricing Model, currency risk, European Monetary Union

\section{INTRODUCTION}

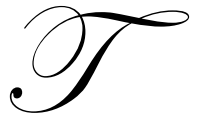

he creation of the European Monetary Union (EMU) in 1991 provides a unique opportunity to study the impact of financial liberalization on the integration of capital markets of different countries in Europe. The main objective of this paper is to estimate the time-varying financial market integration process for both EMU and Non-EMU countries. We assume an International Asset Pricing Model (IAPM) proposed in Adler and Dumas (1983) and estimate the integration process for the regional European market using a sample of three EMU (France, Germany, Netherlands) and two non-EMU (U.K. and Switzerland) countries using monthly data from March 1984 to November 2002. Our main focus is to examine the impact on market and currency risks with the process of regional integration in the European capital markets. Specifically, we investigate whether this process is similar or different for the EMU and Non- EMU countries. We employ the regime-switching model of Bekaert and Harvey (1995) but modify their asset pricing specification to include currency risk as well as market risk. Our specification is similar to that in Hardouvelis et al (2005) and Adler and Qi (2003) but unlike the separate estimations for individual countries in these papers, we conduct joint estimation of the system for our five sample countries.

Our main findings are as follows. First, we find that financial integration in Europe followed a gradual process and did not jump to full integration even after the introduction of the Euro in 1999. We also find that the Euro countries generally display higher degrees of market integration compared to the non-Euro countries in our sample. We find that countries with higher degrees of financial integration tend to have lower prices for market and currency risk, consistent with the prediction of most theoretical models of capital market integration. We also find that prices of market and currency risks are significant and time varying in our sample. These results are consistent with prior research on financial integration, including Errunza and Losq (1985), Bekaert, and Harvey (1995), and Bekaert et al (2002), among others, in the sense that once governments started moving towards reducing crossborder capital controls, the financial markets of corresponding countries started to display signs of higher integration.

Our study makes several contributions to the literature. First, several studies have examined the capital market integration in the EMU using different methodologies but the evidence is mixed. Carrieri (2001) uses a single-regime asset pricing model and finds evidence suggesting that European prices of market and currency risks decreased with financial liberalization through time. Sentana (2002), on the other hand, uses a similar model and 
finds evidence that the creation of the EMU reduced exchange rate and interest rate volatility but he rejects the hypothesis of European market integration. Hardouvelis et al. (2005) use a regime-switching model, and find that integration in European equity markets substantially increased after 1995. Fratzscher (2002) also discovers an increase in the degree of integration for European countries, especially since 1996 using a similar methodology. However, both Hardouvelis, et al (2005) and Fratzscher (2002) use estimation procedures that involve several steps. In addition, their market integration measures are different from those used in Bekaert and Harvey (1995) as they are (in theory and in some cases in practice) not confined to $[0,1]$. Our study differs from the previous research in that we perform a joint estimation of the European stock market returns using a regime-switching model consistent with Bekaert and Harvey (1995) and our measure of integration is restricted to the interval $[0,1]$.

This paper is organized as follows. The next section outlines the theoretical model and estimation method, and section 3 describes the data set. Section 4 presents our finding for the asset pricing processes within Europe. Section 5 concludes.

\section{THEORETICAL MODEL}

Our pricing model includes market and currency risks, as well as regime shifting between segmentation and integration. We start with the model of Adler and Dumas (1983). Under the assumption of fully integrated financial markets the asset pricing relationship is specified as follows:

$$
E_{t-1}\left[r_{i, t}\right]=\sum_{j=1}^{L} \delta_{j, t-1} \operatorname{cov}_{t-1}\left[r_{i, t}, \pi_{j, t}\right]+\delta_{M, t-1} \operatorname{cov}_{t-1}\left[r_{i, t}, r_{M, t}\right]
$$

In this model there are $L+1$ countries, $r_{i, t}$ is the excess return for market index in country $\mathrm{i}$, and $r_{M, t}$ is the excess return for the world market portfolio at time $t, \pi_{j, t}$ is country $j$ 's inflation rate, all in reference currency (US dollars in present study), the currency $j$ 's risk is measured by $\operatorname{cov}_{t-1}\left[r_{i, t}, \pi_{j, t}\right]$ and $\delta_{j, t-1}$ is the price of currency risk. Finally, the market risk is measured by $\operatorname{cov}_{t-1}\left[r_{i, t}, r_{M, t}\right]$ and $\delta_{M, t-1}$ is the price of the market risk.

Following Dumas and Solnik (1995) and De Santis and Gerard (1998) we also assume that domestic inflation is non-stochastic. In such a case foreign exchange risk becomes the only component of the additional exposure faced by an investor who holds asset $i$ with respect to currency $j$. Thus, $\operatorname{cov}_{t-1}\left[r_{i, t}, \pi_{j, t}\right]$ is approximated by $\operatorname{cov}_{t-1}\left[r_{i, t}, e_{j, t}\right]$, where $e_{j, t}$ denotes change in the exchange rate of currency $j$ with respect to the US dollar, and equation (1) can be rewritten as follows:

$$
E_{t-1}\left[r_{i, t}\right]=\sum_{j=1}^{L} \delta_{j, t-1} \operatorname{cov}_{t-1}\left[r_{i, t}, e_{j, t}\right]+\delta_{M, t-1} \operatorname{cov}_{t-1}\left[r_{i, t}, r_{M, t}\right]
$$

The model in equation (2) is based on a rather strong assumption of full integration of the capital markets. Bekaert and Harvey (1995) relax this assumption and explicitly account for the degree of market integration; however, their model includes only market risks. De Santis and Gerard (1998) allow for market and currency risks, as well as the possibility of partial integration by adding country-specific market risk, but they do not quantify the degree of integration for a particular country.

To extend model (2) and allow regime shifting, we follow Bekaert and Harvey (1995) and introduce a state variable $\varphi_{j, t-1}$ that indicates time-varying degree of integration. Our asset pricing model includes global market and currency risks, as well as local market risks for each country. In light of Adler and Dumas (1983) model, this specification translates into the following: 


$$
\begin{aligned}
E_{t-1}\left[r_{j, t}\right]=\varphi_{j, t-1}\left(\delta_{M, t-1} \operatorname{cov}_{t-1}\left[r_{j, t}, r_{M, t}\right]+\right. & \left.\sum_{j=1}^{L} \delta_{j, t-1} \operatorname{cov}_{t-1}\left[r_{i, t}, e_{j, t}\right]\right)+ \\
& +\left(1-\varphi_{j, t-1}\right) \delta_{j, m, t-1} \operatorname{var}_{t-1}\left[r_{j, t}\right]
\end{aligned}
$$

Equation (3) encompasses the IAPM of Adler and Dumas (1983) and the classical CAPM of Sharpe (1964) and Lintner (1965). Full integration is denoted by $\varphi_{j, t-1}=1$, which results in the expected market excess return in country $j$ being a function of price of currency risk $\delta_{c, t-1}$, the covariance of excess asset and currency returns $\operatorname{cov}_{t-1}\left[r_{j, t}, r_{c, t}\right]$, the price of market risk $\delta_{M, t-1}$, and the covariance of the country $j$ market excess return and the excess return on the international market portfolio $\operatorname{cov}_{t-1}\left[r_{j, t}, r_{M, t}\right]$. In other words, if the market in country $j$ is fully integrated with the other countries, then investors are compensated for their exposure to both the market risk and the currency risk stemming from uncertainty with respect to the purchasing power of returns earned in country $j$ and spent in other countries.

In the case of fully segmented market, stringent government controls on cross-border capital flows restrict or prohibit international investments. In such a case, the returns earned in country $\mathrm{j}$ have purchasing power only in country $\mathrm{j}$, and thus only the risk-return relationship within country $\mathrm{j}$ is relevant, as is the case in the traditional CAPM. Therefore, if the market in country $j$ is fully segmented from the international marketplace, $\varphi_{j, t-1}=0$ and the expected market excess return in country $j$ is a function of only the local market price of risk $\delta_{j, m, t-1}$ and its own variance $\operatorname{var}_{t-1}\left[r_{j, t}\right]$.

\section{EMPIRICAL METHOD}

We estimate the regime-switching international asset pricing model (3) jointly for all countries using the multivariate GARCH methodology with regime switching in the mean equations. We extend the methodology of Bekaert and Harvey (1995) by adding currency risk to the mean equations, as well as by using variance targeting and adding conditional covariances to the variance equations. In order to reduce the number of equations, we use a currency index instead of bilateral exchange rates. Thus, we have the following specification:

$$
\begin{aligned}
r_{i, t}=\varphi_{i, t-1}\left(\delta_{M, t-1} \operatorname{cov}_{t-1}[\right. & \left.\left.r_{i, t}, r_{M, t}\right]+\delta_{c, t-1} \operatorname{cov}_{t-1}\left[r_{i, t}, r_{c, t}\right]\right)+ \\
& +\left(1-\varphi_{i, t-1}\right) \delta_{i, m, t-1} \operatorname{var}_{t-1}\left[r_{i, t}\right]+e_{i, t}
\end{aligned}
$$

where $r_{i, t}$ is excess return on country $i$ 's market index, $\delta_{M, t-1}$ is price of international market risk, $\operatorname{cov}_{t-1}\left[r_{i, t}, r_{M, t}\right]$ denotes country $i$ 's exposure to international market risk, $\delta_{c, t-1}$ is the price of currency risk given information available at time $t-1, \operatorname{cov}_{t-1}\left[r_{i, t}, r_{c, t}\right]$ denotes country $i$ 's currency exposure, and $e_{i, t}$ is residual at time $t$.

We have two more elements in the system. First, international market excess return is:

$r_{M, t}=\delta_{M, t-1} \operatorname{var}_{t-1}\left(r_{M, t}\right)+\delta_{c, t-1} \operatorname{cov}_{t-1}\left(r_{M}, r_{c}\right)+e_{M, t}$,

and the currency index return is:

$r_{c, t}=\delta_{M, t-1} \operatorname{cov}_{t-1}\left(r_{M}, r_{c}\right)+\delta_{c, t-1} \operatorname{var}_{t-1}\left(r_{c, t}\right)+e_{c, t}$ 
We estimate the prices of international market risk and of local market risk as follows:

$\delta_{M, t-1}=\exp \left[\mathrm{Z}_{t-1}^{E U} \mathrm{k}_{1}\right]$

and

$\delta_{i, m, t-1}=\exp \left[\mathrm{Z}_{t-1}^{m, i} \mathrm{k}_{1, i}\right]$

where $\mathrm{Z}_{t-1}^{E U}$ is a set of international information variables, $\mathrm{k}_{1}$ is a vector of coefficients, $\mathrm{Z}_{t-1}^{m, i}$ is a set of countryspecific pricing information variables for country $i$, and $\mathrm{k}_{1, i}$ is a vector of coefficients for country $i$. Model (1) places no restriction on the sign of the price of currency risk, therefore, we specify it as a linear function:

$\delta_{c, t-1}=\mathrm{Z}_{t-1}^{E U} \mathrm{k}_{2}$

where $\mathrm{k}_{2}$ is a vector of coefficients.

System (4), (5), and (6) includes a measure of country i's integration $\varphi_{i, t-1}$. Following Bekaert and Harvey (1995), we estimate it as a logistic function:

$\varphi_{i, t-1}=\frac{\exp \left(\mathrm{Z}_{t-1}^{\varphi, i} \mathrm{k}_{3, i}\right)}{1+\exp \left(\mathrm{Z}_{t-1}^{\varphi, i} \mathrm{k}_{3, i}\right)}, i=1, \ldots, 5$

Elements of equation (10) include $\mathrm{Z}_{t-1}^{\varphi, i}$, a set of instrumental variables providing information related to the degree of integration, and $\mathrm{k}_{3, i}$, a vector of coefficients corresponding to the integration measure of country $i$.

Excess returns in the full integration model (4), (5), and (6) are assumed to be jointly normally distributed, $e_{t} \equiv\left(e_{1, t}, \ldots, e_{5, t}, e_{M, t}, e_{F X, t}\right)^{\prime} \sim N\left(0, \mathrm{H}_{t}\right)$.

We estimate the system using a multivariate GARCH specification for the variance-covariance matrix $\mathrm{H}_{t}$,

$\mathrm{H}_{t}=\mathrm{H}_{0} \circ\left(\mathrm{ii}^{\prime}-A A^{\prime}-B B^{\prime}\right)+A \mathrm{e}_{t-1} \mathrm{e}_{t-1}^{\prime} A^{\prime}+B \mathrm{H}_{t-1} B^{\prime}$

where, $\mathrm{H}_{0}$ is an unconditional $7 \mathrm{x} 7$ variance-covariance matrix, $\mathrm{e}_{t-1}$ is a $7 \mathrm{x} 1$ vector of residuals at time $t$, $\mathrm{i}$ is a $7 \mathrm{x} 1$ vector of ones, $\mathrm{A}$ and $\mathrm{B}$ are $7 \mathrm{x} 7$ diagonal matrices of coefficients, and finally “ $\circ$ " denotes Hadamard matrix product or element by element multiplication.

The system was estimated using the Marquardt algorithm under an assumption of multivariate normality. To ensure that coefficient estimates correspond to the global maximum of the log likelihood function $l(\Theta)$ with respect to parameter space $\Theta$,

$l(\Theta)=-\frac{1}{2}\left(T \ln 2 \pi+\sum_{t=1}^{T} \ln \left|\mathrm{H}_{t}\right|+\sum_{t=1}^{T} \mathrm{e}_{t}^{\prime} \mathrm{H}_{t}^{-1} \mathrm{e}_{t}\right)$,

we used a number of different combinations of starting values for estimation. 


\section{DATA}

We analyze the influence of European unification on stock markets in five countries, including three EMU (France, Germany, the Netherlands) and two non-EMU (U.K. and Switzerland) countries. We use monthly returns from March 1984 to November 2002 for five European stock market indices, as well as returns for the European market index. In addition, we construct the US trade weighted index against major currencies as a common measure of the currency exposure. See Jorion (1990), Ferson and Harvey (1993, 1994), Carrieri et al. (2003). In constructing the currency index, we follow Carrieri, Errunza, and Majerbi (2003) and use log changes in the inverse of the tradeweighted US foreign exchange index against major currencies $r_{c, t}$. Alternatively, one could follow Hardouvelis et al (2005) or Fratzscher (2002) and estimate pricing relationships for each county separately, but this would result in obtaining coefficients given by local maxima (as opposed to the global maximum) in the maximum likelihood estimation.

Stock market data are obtained from Morgan Stanley Capital International. We used the US dollardenominated MSCI gross index series to calculate stock returns. The data on dividend yields and short- and longterm riskless rates for European countries is obtained from the dataset that accompanies the Solnik and McLeavey (2002) textbook on international investments. The data on the US trade-weighted foreign exchange index, Eurodollar rate, and the US government bond yields are obtained from the US Federal Reserve Board website. The paper measures the riskless rate as the 1-month Eurodollar rate. Altogether, the system consists of seven equations: five country indices, the European market index, and the currency index.

Panel A. Descriptive statistics

Table 1. Summary statistics for market returns and the currency index

\begin{tabular}{lccccccc}
\hline & Germany & France & Netherlands & $\begin{array}{c}\text { United } \\
\text { Kingdom }\end{array}$ & Switzerland & Europe & $\begin{array}{c}\text { Exchange } \\
\text { Rate Index }\end{array}$ \\
\hline Mean & 0.001988 & 0.003460 & 0.004848 & 0.001442 & 0.005202 & 0.002695 & 0.000867 \\
Std. Dev. & 0.078020 & 0.074471 & 0.066428 & 0.064653 & 0.067204 & 0.050120 & 0.017234 \\
Skewness & -0.698179 & -0.234349 & -0.425549 & -0.538783 & -0.291180 & -0.828402 & 0.224058 \\
Kurtosis & 4.615945 & 3.629655 & 4.289202 & 5.177314 & 4.019578 & 4.655856 & 3.019647 \\
Jarque-Bera & $42.76026^{* * *}$ & $5.776345^{*}$ & $22.37258^{* * *}$ & $55.32979^{* * *}$ & $12.92514^{* * *}$ & $51.43929^{* * *}$ & 1.886186 \\
ADF Statistics*********⿲二丨匕 & $-17.50456^{* * *}$ & $-16.66553^{* * *}$ & $-17.90298^{* * *}$ & $-18.60905^{* * *}$ & $-16.50127^{* * *}$ & $-15.55878^{* * *}$ & $-10.44287^{* * *}$ \\
\hline
\end{tabular}

Notes: Descriptive statistics for market returns and the currency index. Country returns for Germany, France, Netherlands, United Kingdom, and Switzerland, in excess of their riskless rates. MSCI Europe return in excess of 1-month Eurodollar rate. All returns converted into \$US terms. Exchange rate index is constructed using the US trade-weighted index against major currencies. Sample range is 3/1984-11/2002.

${ }^{* * *}$ indicates $1 \%$ significance, ${ }^{* *}$ indicates $5 \%$ significance, ${ }^{*}$ indicates $10 \%$ significance

* Null hypothesis is that a series contains unit root. Significance levels determined using MacKinnon (1996) one-sided p-values.

Panel B. Correlation matrix

\begin{tabular}{|c|c|c|c|c|c|c|c|}
\hline & Germany & France & Netherlands & $\begin{array}{c}\text { United } \\
\text { Kingdom }\end{array}$ & Switzerland & Europe & $\begin{array}{c}\text { Exchange } \\
\text { Rate Index }\end{array}$ \\
\hline Germany & 1.000000 & & & & & & \\
\hline France & 0.827167 & 1.000000 & & & & & \\
\hline Netherlands & 0.838374 & 0.821391 & 1.000000 & & & & \\
\hline UK & 0.644935 & 0.695730 & 0.758535 & 1.000000 & & & \\
\hline Switzerland & 0.746793 & 0.754222 & 0.825044 & 0.713117 & 1.000000 & & \\
\hline Europe & 0.799003 & 0.783136 & 0.768041 & 0.742887 & 0.702916 & 1.000000 & \\
\hline $\begin{array}{l}\text { Exchange Rate } \\
\text { Index }\end{array}$ & 0.074752 & 0.159928 & 0.110074 & 0.205503 & 0.163808 & 0.223805 & 1.000000 \\
\hline
\end{tabular}

Table 1 presents descriptive statistics for the country excess returns and the currency return. Switzerland displays the highest mean excess return of $0.5202 \%$ per month or roughly $6.4 \%$ annualized return, while Germany has the lowest mean return of 0.1988 per month or $1.7 \%$ annualized return. Germany also had the largest stock return standard deviation of 0.07802, whereas the European market index has the standard deviation of 0.05012, the smallest among all monthly stock returns. For all stock return series, the hypothesis of normality is rejected by the Jarque-Bera statistic, and all series are stationary according to the ADF test. Table 1 Panel B shows substantial 
cross-correlations of all stock returns and relatively lower correlation of the stock returns and the currency index.

Table 2. Summary statistics for European information variables.

Panel A. Descriptive statistics

\begin{tabular}{lcccc}
\hline & XER & $\Delta$ USTP & USDP & XEDY \\
\hline Mean & 0.002553 & -0.001378 & 0.953778 & -0.001165 \\
Std. Dev. & 0.050026 & 0.159394 & 0.311533 & 0.029701 \\
Skewness & -0.828537 & 0.117364 & 0.787159 & -0.020619 \\
Kurtosis & 4.677418 & 4.155019 & 2.860512 & 3.755838 \\
Jarque-Bera & $52.12149^{* * *}$ & $13.02342^{* * *}$ & $23.41814^{* * *}$ & $5.371797^{*}$ \\
ADF Statistics* & $-15.61771^{* * * *}$ & $-10.67569^{* * *}$ & $-3.292130^{* * *}$ & $-14.03758^{* * *}$ \\
\hline
\end{tabular}

Notes: Descriptive statistics for European information variables. The symbols are as follows:

XER is lagged European stock return in excess of 1-month Eurodollar rate, $\Delta$ USTP is lagged change in the US term premium ${ }^{1}$, where term premium is calculated as a difference between 7-year and 1-year US Government bond yields, USDP is lagged US default premium, calculated as the difference between Aaa and Baa US corporate bond yields, XEDY is lagged European dividend yield, in US dollar terms, in excess of 1-month Eurodollar rate. Sample range is 3/1984-11/2002.

${ }^{* * *}$ indicates $1 \%$ significance, ${ }^{* *}$ indicates $5 \%$ significance, ${ }^{*}$ indicates $10 \%$ significance

* Null hypothesis is that a series contains unit root. Significance levels determined using MacKinnon (1996) one-sided p-values.

${ }^{1}$ ADF test statistic for level of US term premium is $\mathrm{t}=-2.109039$, $\mathrm{p}$-value 0.2414 .

Panel B. Correlation matrix

\begin{tabular}{lcccc}
\hline & XER & $\Delta$ USTP & USDP & XEDY \\
\hline XER & 1.000000 & & & \\
$\Delta$ USTP & -0.043932 & 1.000000 & 1.000000 & 1.000000 \\
USDP & 0.059265 & -0.020779 & 0.059236 & \\
XEDY & -0.109444 & -0.052832 & & \\
\hline
\end{tabular}

Several previous studies, including Dumas and Solnik (1995), De Santis and Gerard (1998), or Carrieri (2001), use a set of instrumental variables that convey information about the market and economic conditions in the European marketplace, as well as in each country. We use these variables in pricing equations to compute prices of market and currency risks. The instrumental variables used in measuring integration are constructed in such a way that they reflect any differences in economic conditions between each specific country and the European market.

European information variables include a constant, the MSCI Europe index return in excess of one-month Eurodollar rate (XER), the European dividend yield in excess of one-month Eurodollar rate (XEDY), the US default premium (USDP) and a change in the US term premium ( $\triangle$ USTP), all lagged one month. Data series for the European term structure and the default premium for the whole sample were not available; we use corresponding US variables as proxies. The term structure variable is calculated as the difference between the 7-year US government bond yield and the 1-year US government bond yield. The default premium is calculated as a difference between the Baa and Aaa corporate bond yields in Moody's classification, available at the US Federal Reserve Board's website.

Descriptive statistics for the European information variables are presented in Table 2. All variables are stationary according to the ADF test statistic, and the null hypothesis of normal distribution is strongly rejected for all series based on the Jarque-Bera test. The cross-correlations of the information variables range from - 0.109444 to 0.059265 .

Country-specific information variables include two subsets. The first subset characterizes particular countries and contains four variables, a constant, a local market return in excess of the corresponding riskless rate (XLR), a country-specific term premium (LTP), and a country-specific dividend yield (XLDY) in excess of the corresponding riskless rate. Several previous studies, including Bekaert and Harvey (1995), De Santis and Gerard (1998), Carrieri (2001), De Santis et al (2003), Carrieri et al. (2003) have shown that these variables have the ability to forecast future economic conditions in a country. The second subset characterizes how a specific country's economy differs from the aggregate European economy. These variables include the absolute difference between the country's excess returns and European excess returns (ADXR), the difference between the country's term premium 
(the country's government bond rate less this country's short-term riskless rate, adjusted for the change in the corresponding exchange rate) and the US term premium (DTP), and the difference between a particular country's dividend yield and the European dividend yield (DDY). We follow Fedorov and Sarkissian (2000) in constructing variable ADXR. In fact, we tried both absolute deviation and a simple return difference as an instrument and obtained similar results. Next, we construct variables DTP and DDY using logic analogous to Fedorov and Sarkissian (2000, p. 139). All variables are lagged one month. The first three variables are used in the asset pricing model. The other three variables are used as instrumental variables to determine a specific country's degree of integration.

Table 3. Summary statistics for country information variables

Panel A1. Descriptive statistics for Germany

\begin{tabular}{lcccccc}
\hline & & \multicolumn{2}{c}{ Pricing Instruments } & \multicolumn{3}{c}{ Integration Instruments } \\
\hline & XLR & LTP & XLDY & ADXR & DTP & DDY \\
\hline Mean & 0.002113 & 0.002714 & 0.004228 & 0.037978 & 0.001417 & 0.000409 \\
Std. Dev. & 0.078039 & 0.032683 & 0.032701 & 0.029844 & 0.032610 & 0.011859 \\
Skewness & -0.702276 & -0.095943 & -0.079021 & 1.217204 & -0.110314 & -0.051925 \\
Kurtosis & 4.615850 & 3.520253 & 3.472248 & 4.946791 & 3.515311 & 3.763752 \\
Jarque-Bera & $42.97252^{* * *}$ & 2.882652 & 2.324957 & $91.09069^{* * *}$ & 2.945834 & $5.569710^{*}$ \\
ADF Statistics* & $-17.60803^{* * *}$ & $-14.42357^{* * *}$ & $-14.44821^{* * *}$ & $-14.92955^{* * *}$ & $-14.49000^{* * *}$ & $-16.10575^{* * *}$ \\
\hline
\end{tabular}

Panel B1. Correlation matrix for Germany

\begin{tabular}{|c|c|c|c|c|c|c|}
\hline & XLR & LTP & XLDY & ADXR & DTP & DDY \\
\hline XLR & 1.000000 & & & & & \\
\hline LTP & -0.506015 & 1.000000 & & & & \\
\hline XLDY & -0.509570 & 0.999374 & 1.000000 & & & \\
\hline ADXR & -0.167557 & 0.013264 & 0.014580 & 1.000000 & & \\
\hline DTP & -0.507658 & 0.999800 & 0.998993 & 0.011945 & 1.000000 & \\
\hline DDY & -0.304194 & 0.423037 & 0.426634 & -0.026854 & 0.421093 & 1.000000 \\
\hline
\end{tabular}

Panel A2. Descriptive statistics for France

\begin{tabular}{lcccccc}
\hline & XLR & LTP & XLDY & ADXR & DTP & DDY \\
\hline Mean & 0.003314 & 0.002460 & 0.004402 & 0.036925 & 0.001157 & $8.38 \mathrm{E}-05$ \\
Std. Dev. & 0.074187 & 0.031791 & 0.031900 & 0.029022 & 0.031724 & 0.010855 \\
Skewness & -0.229663 & -0.135792 & -0.103805 & 1.076149 & -0.148517 & 0.127100 \\
Kurtosis & 3.651348 & 3.561762 & 3.513881 & 3.954343 & 3.562425 & 4.376568 \\
Jarque-Bera & $6.008272^{* *}$ & 3.682448 & 2.905365 & $52.42905^{* * *}$ & 3.826380 & $18.53414^{* * *}$ \\
ADF Statistics* & $-16.71370^{* * *}$ & $-14.40415^{* * *}$ & $-14.34479^{* * *}$ & $-13.39540^{* * *}$ & $-14.45865^{* * *}$ & $-15.93073^{* * *}$ \\
\hline
\end{tabular}

Panel B2. Correlation matrix for France

\begin{tabular}{|c|c|c|c|c|c|c|}
\hline & XLR & LTP & XLDY & ADXR & DTP & DDY \\
\hline$\overline{\text { XLR }}$ & 1.000000 & & & & & \\
\hline LTP & -0.568999 & 1.000000 & & & & \\
\hline XLDY & -0.567280 & 0.999096 & 1.000000 & & & \\
\hline ADXR & 0.135001 & -0.086787 & -0.085537 & 1.000000 & & \\
\hline DTP & -0.570822 & 0.999788 & 0.998433 & -0.089050 & 1.000000 & \\
\hline DDY & -0.305755 & 0.334391 & 0.339721 & -0.186505 & 0.332803 & 1.000000 \\
\hline
\end{tabular}

Panel A3. Descriptive statistics for the Netherlands

\begin{tabular}{|c|c|c|c|c|c|c|}
\hline & & \multicolumn{2}{|c|}{ Pricing Instruments } & \multicolumn{3}{|c|}{ Integration Instruments } \\
\hline & XLR & LTP & XLDY & ADXR & DTP & DDY \\
\hline Mean & 0.004944 & 0.003252 & 0.005415 & 0.033126 & 0.001950 & 0.001097 \\
\hline Std. Dev. & 0.066148 & 0.032935 & 0.033155 & 0.026417 & 0.032852 & 0.011086 \\
\hline Skewness & -0.431384 & -0.049481 & -0.019509 & 0.855608 & -0.063599 & 0.003742 \\
\hline Kurtosis & 4.326024 & 3.489929 & 3.423522 & 3.099777 & 3.484231 & 3.401248 \\
\hline Jarque-Bera & $23.67147^{* * *}$ & 2.362915 & 1.710949 & $27.79059^{* * *}$ & 2.370814 & 1.523322 \\
\hline ADF Statistics* & $-17.94538^{* * *}$ & $-14.29833^{* * *}$ & $-14.17179^{* * * *}$ & $-16.52084^{* * *}$ & $-14.36453^{* * *}$ & $-15.12481^{* * *}$ \\
\hline
\end{tabular}


Table 3. Summary statistics for country information variables (continued)

Panel B3. Correlation matrix for the Netherlands

\begin{tabular}{|c|c|c|c|c|c|c|}
\hline & XLR & LTP & XLDY & ADXR & DTP & DDY \\
\hline$\overline{\text { XLR }}$ & 1.000000 & & & & & \\
\hline LTP & -0.618495 & 1.000000 & & & & \\
\hline XLDY & -0.618428 & 0.999225 & 1.000000 & & & \\
\hline ADXR & 0.104891 & -0.103245 & -0.101120 & 1.000000 & & \\
\hline DTP & -0.620436 & 0.999804 & 0.998679 & -0.104319 & 1.000000 & \\
\hline DDY & -0.385026 & 0.433260 & 0.438027 & -0.017336 & 0.430660 & 1.000000 \\
\hline
\end{tabular}

Panel A4. Descriptive statistics for the UK

\begin{tabular}{|c|c|c|c|c|c|c|}
\hline & XLR & LTP & XLDY & ADXR & DTP & DDY \\
\hline Mean & 0.001579 & 0.000918 & 0.004357 & 0.032389 & -0.000385 & $3.88 \mathrm{E}-05$ \\
\hline Std. Dev. & 0.064535 & 0.031246 & 0.031437 & 0.028863 & 0.031246 & 0.014704 \\
\hline Skewness & -0.539761 & -0.079957 & 0.005956 & 1.450160 & -0.100564 & -0.326429 \\
\hline Kurtosis & 5.177611 & 5.492346 & 5.557164 & 5.206732 & 5.471331 & 3.910608 \\
\hline Jarque-Bera & $55.87377^{\text {*** }}$ & $58.99505^{* * *}$ & $61.85023^{* * *}$ & $125.6210^{\text {**** }}$ & $58.14915^{* * * *}$ & $11.87428^{\text {**** }}$ \\
\hline ADF Statistics* & $-18.65752^{* * *}$ & $-14.21196^{* * *}$ & $-14.21158^{* * *}$ & $-14.39726^{* * *}$ & $-14.21036^{* * *}$ & $-13.52097^{* * *}$ \\
\hline
\end{tabular}

Panel B4. Correlation matrix for the UK

\begin{tabular}{lcccccc}
\hline & XLR & LTP & XLDY & ADXR & DTP & DDY \\
\hline XLR & 1.000000 & & & & & \\
LTP & -0.571641 & 1.000000 & & & & \\
XLDY & -0.571373 & 0.998604 & 1.000000 & & & \\
ADXR & -0.118668 & 0.119392 & 0.129552 & 1.000000 & & \\
DTP & -0.572383 & 0.999779 & 0.998317 & 0.117582 & 1.000000 & 1.000000 \\
DDY & -0.115049 & 0.333293 & 0.329179 & 0.025602 & 0.337076 \\
\hline
\end{tabular}

Panel A5. Descriptive statistics for Switzerland

\begin{tabular}{|c|c|c|c|c|c|c|}
\hline & & \multicolumn{3}{|c|}{ Pricing Instruments } & \multicolumn{2}{|c|}{ Integration Instruments } \\
\hline & XLR & LTP & XLDY & ADXR & DTP & DDY \\
\hline Mean & 0.004853 & 0.003140 & 0.004375 & 0.038260 & 0.001837 & $5.69 \mathrm{E}-05$ \\
\hline Std. Dev. & 0.067116 & 0.035197 & 0.035336 & 0.029280 & 0.035113 & 0.014414 \\
\hline Skewness & -0.281570 & 0.068061 & 0.085736 & 1.385106 & 0.053562 & 0.293251 \\
\hline Kurtosis & 4.007780 & 3.182503 & 3.149185 & 6.427173 & 3.172706 & 4.126299 \\
\hline Jarque-Bera & $12.60556^{* * *}$ & 0.490288 & 0.488607 & $183.6769^{* * *}$ & 0.390657 & $15.25190^{\text {*** }}$ \\
\hline ADF Statistics* & $-16.58114^{* * *}$ & $-13.69135^{\text {*** }}$ & $-13.63801^{\text {*** }}$ & $-15.76126^{* * *}$ & $-13.74765^{* * *}$ & $-14.58466^{* * *}$ \\
\hline
\end{tabular}

Panel B5. Correlation matrix for Switzerland

\begin{tabular}{|c|c|c|c|c|c|c|}
\hline & XLR & LTP & XLDY & ADXR & $\overline{\text { DTP }}$ & DDY \\
\hline XLR & 1.000000 & & & & & \\
\hline LTP & -0.607634 & 1.000000 & & & & \\
\hline XLDY & -0.608281 & 0.999292 & 1.000000 & & & \\
\hline ADXR & 0.109203 & -0.096782 & -0.095791 & 1.000000 & & \\
\hline DTP & -0.610199 & 0.999828 & 0.998992 & -0.097937 & 1.000000 & \\
\hline DDY & -0.332383 & 0.544471 & 0.546045 & -0.084898 & 0.543184 & 1.000000 \\
\hline
\end{tabular}

Notes: Local information variables for Germany, France, Netherlands, United Kingdom, and Switzerland. XLR is lagged market return in excess of corresponding riskless rate, LTP is a lag in the corresponding term premium, LXDY is lagged country dividend yield converted into US dollar terms, ADXR is absolute difference between a country's excess return and European excess return, DTP is a difference in term premiums between a particular country and Europe (proxied by US term premium), and DDY is a difference between dividend yield in a specific country and European dividend yield. Sample size is 225 observations. $^{* * *}$ indicates $1 \%$ significance, ${ }^{* *}$ indicates $5 \%$ significance, ${ }^{*}$ indicates $10 \%$ significance

* Null hypothesis is that a series contains unit root. Significance levels determined using MacKinnon (1996) one-sided p-values. 
Descriptive statistics for the local information variables are presented in Table 3. All series are stationary according to the ADF test statistics. The null hypothesis of normality for variable XLR (lagged local market return in excess of the corresponding riskless rate) and variable ADXR (absolute difference between a country's excess return and the European excess return) is strongly rejected for all countries. In addition, the hypothesis of normality is rejected for variable DDY (difference between a local dividend yield and the European dividend yield) for Germany, France, the UK, and Switzerland. Next, normality is rejected for variable DTP (difference in term premiums between a specific country and the European market, the latter proxied by the US term premium) for the UK. Finally, the local pricing variables (XLR, LTP, and XLDY) display quite high cross-correlations, which should bias the results against finding individual significance of coefficients due to anticipated multicolinearity. Crosscorrelations among integration variables (ADXR, DTP, and DDY) are not as large as those among the pricing variables.

\section{EMPIRICAL RESULTS}

In this section we discuss estimation results for system (4), (5), and (6), which assumes that degree of market integration varies over time. The econometric model is based on the IAPM and on empirical work of Bekaert and Harvey (1995), Hardouvelis et al (2005), and theoretical models of Errunza and Losq (1985) and Bhamra (2002). The estimation of this model is presented in Table 4.

An interesting observation emerges from inspection of signs of the local coefficients compared with the signs of the European coefficients. Whereas the coefficient for the European market excess return XER is positive and significant, all but one (Switzerland) coefficients for corresponding local excess returns XLR are negative; the local coefficients are significant at the $1 \%$ level for Germany and Netherlands and at the 5\% level for the UK. It appears that an increase in the overall European excess return increases the price of European market risk, while an increase in individual country returns should decrease the price of local market risk. This would make sense when investors exhibit increasing relative risk aversion while investing into the European market, and decreasing relative risk aversion in investment decisions within their home countries. We hypothesize that such seemingly contradictory results may be related to home bias, a situation where investors allocate funds into their own country more frequently than abroad, perhaps because they are less risk averse with respect to their home market. (See Cooper and Kaplanis (1994). There may be some alternative explanations for this phenomenon; we leave a more detailed investigation for the future.).

Residual diagnostics in Table 5 show that most standardized residuals have considerable kurtosis and are non-normal except for France and the currency index, consistent with the results obtained for the full integration model. Most p-values of Ljung-Box statistics are once again above $10 \%$ level, which suggests that most mean, variance, and covariance equations are adequate; however, the diagonal BEKK parameterization does not fully capture the dynamics of the system.

To investigate whether our empirical model produces meaningful results, we check if European prices of market and currency risks are zero or constant, and if the estimated coefficients corresponding to the variancecovariance matrix are individually highly significant and satisfy the stationarity condition. The test results indicate that our time-varying integration model is "well-behaved", since the estimation results are consistent with those presented in Dumas and Solnik (1995), De Santis and Gerard (1998), Carrieri (2001), or Carrieri et al. (2003). We do not present test results here due to space considerations, but they are available from the authors upon request.

We plot integration measures in Figure 1. The highest level of integration is displayed by France, which is immediately followed by Germany, and the lowest integration level is displayed by the UK. This is what we expected, since the theory predicts that a common currency should reduce transaction costs and increase market integration across countries. Thus, the EMU countries (France and Germany) should have higher degree of market integration than a non-EMU country (the U.K.). 
Table 4. Coefficient estimates for the IAPM with time-varying prices of risk and time-varying integration

Price of European market risk

\begin{tabular}{llllll}
\hline & Constant & XER & $\Delta$ USTP & USDP & XEDY \\
\hline Coefficient & $-1.111414^{* * *}$ & $9.480548^{* * *}$ & -0.858417 & $1.629568^{* * *}$ & $33.03236^{* * *}$ \\
Std. Error & 0.506261 & 2.609344 & 0.827804 & 0.418118 & 4.273381 \\
\hline Price of European currency risk & & & & \\
\hline \multicolumn{7}{l}{} & Constant & XER & $\Delta$ USTP & USDP & XEDY \\
\hline Coefficient & -4.113871 & $315.3642^{* * *}$ & 3.330225 & 6.272857 & $1054.214^{* * *}$ \\
Std. Error & 7.085848 & 57.87713 & 16.98780 & 7.647411 & 101.8844 \\
\hline
\end{tabular}

Prices of local market risks

Germany

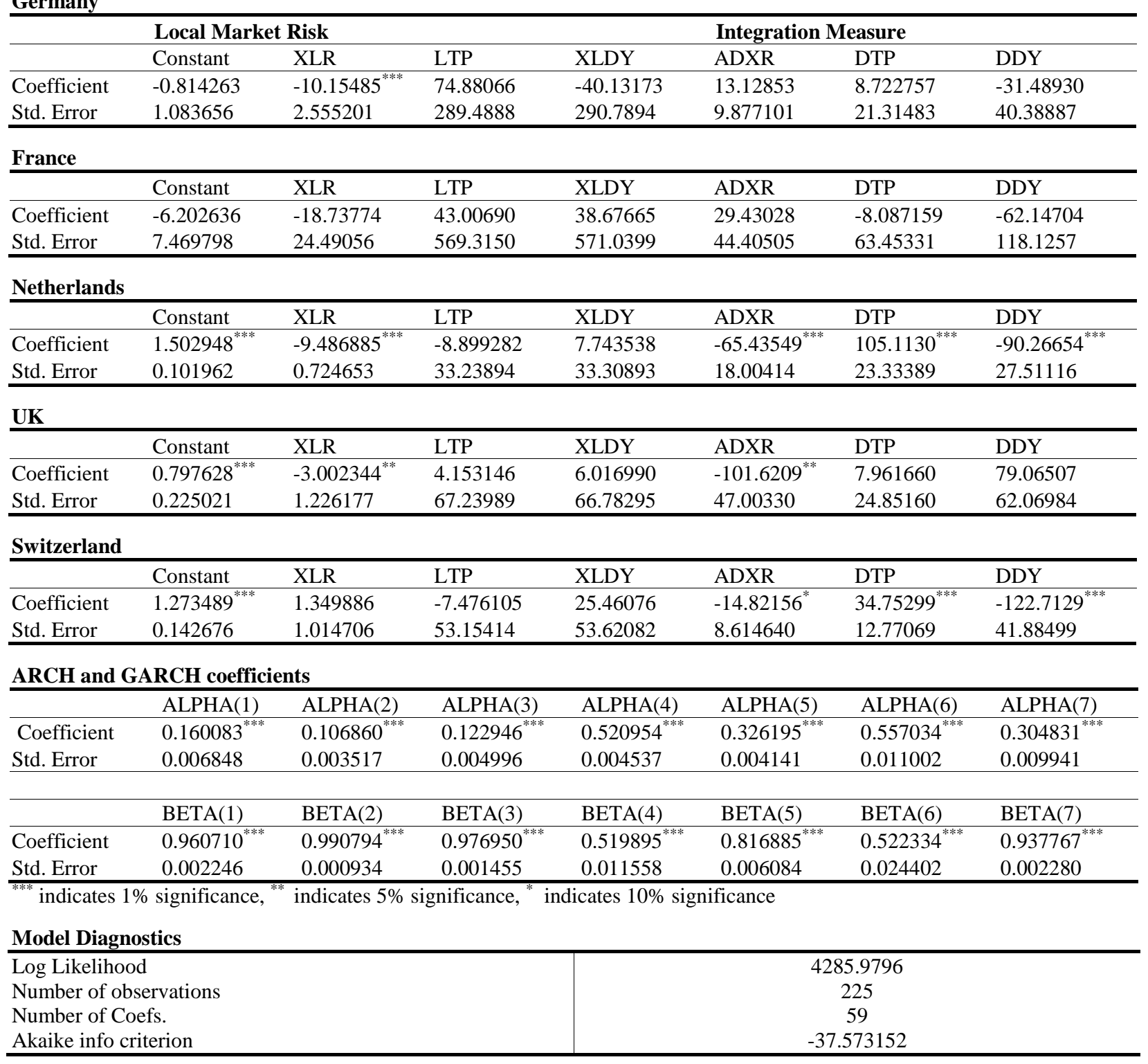


A note of caution is warranted in interpreting the results. All monthly fitted series potentially contain estimation errors. Thus, the integration measure that we use should not be interpreted in a way that the degree of integration between each country and Europe changes on a monthly basis. Instead, analysis of mean values, smoothed series, long-term trends, and simultaneous variations of the integration measures and other relevant variables should provide a more accurate picture of events. In addition, we tried alternative specifications for the integration measure in order to check robustness of the results. The specifications included a functional form used by Fedorov and Sarkissian (2000) $\varphi_{i, t-1}=\frac{1}{1+\exp \left(\mathbf{Z}_{t-1}^{\varphi, i} \mathbf{k}_{3, i}\right)}$, exponential function used by Adler and Qi (2003) $\varphi_{i, t-1}=\exp \left(\mathbf{Z}_{t-1}^{\varphi, i} \mathbf{k}_{3, i}\right)$, and a linear specification $\varphi_{i, t-1}=\mathbf{Z}_{t-1}^{\varphi, i} \mathbf{k}_{3, i}$. All specifications produced similar dynamics of the integration measure in a sense that it did not display a sharp increase after the introduction of Euro. We also estimated a model with a single integration measure for all countries and verified via a likelihood ratio test that levels of integration for different countries are distinct from each other.

An interesting result is discovered by analyzing time varying market integration for the Netherlands and Switzerland. Our estimates for the integration measure for Switzerland, a non-EMU country, are slightly higher than those for the Netherlands, an EMU country, whereas we would expect to observe the opposite. However, given the number of international banks operating in Switzerland, as well as the number of Swiss banks that have investments overseas, it is plausible that Switzerland should have very strong economic ties with other countries even without participating in the EMU. Alternatively, the role of government controls on capital flows across different countries could also explain the differences in the degree of integration across countries.

Table 5. Diagnostics of standardized residuals

\begin{tabular}{|c|c|c|c|c|c|c|c|}
\hline & Germany & France & Netherlands & U.K. & Switzerland & Europe & FX Index \\
\hline Residuals & $e_{1} / h_{1}^{1 / 2}$ & $e_{2} / h_{2}^{1 / 2}$ & $e_{3} / h_{3}^{1 / 2}$ & $e_{4} / h_{4}^{1 / 2}$ & $e_{5} / h_{5}^{1 / 2}$ & $e_{M} / h_{M}^{1 / 2}$ & $e_{c} / h_{c}^{1 / 2}$ \\
\hline $\operatorname{Prob}\left(\mathrm{Q}_{12}\right)$ & 0.532 & 0.919 & 0.362 & 0.404 & 0.562 & 0.922 & 0.057 \\
\hline $\begin{array}{l}\text { Squared } \\
\text { residuals }\end{array}$ & $e_{1}^{2} / h_{1}$ & $e_{2}^{2} / h_{2}$ & $e_{3}^{2} / h_{3}$ & $e_{4}^{2} / h_{4}$ & $e_{5}^{2} / h_{5}$ & $e_{M}^{2} / h_{M}$ & $e_{c}^{2} / h_{c}$ \\
\hline $\operatorname{Prob}\left(\mathrm{Q}_{12}\right)$ & 0.796 & 0.686 & 0.001 & 0.967 & 0.721 & 0.954 & 0.266 \\
\hline Cross-products & & $e_{1} e_{2} / h_{12}$ & $e_{1} e_{3} / h_{13}$ & $e_{1} e_{4} / h_{14}$ & $e_{1} e_{5} / h_{15}$ & $e_{1} e_{M} / h_{1 M}$ & $e_{1} e_{c} / h_{1 c}$ \\
\hline $\operatorname{Prob}\left(\mathrm{Q}_{12}\right)$ & & 0.478 & 0.075 & 0.587 & 0.269 & 0.991 & 0.976 \\
\hline Cross-products & & & $e_{2} e_{3} / h_{23}$ & $e_{2} e_{4} / h_{24}$ & $e_{2} e_{5} / h_{25}$ & $e_{2} e_{M} / h_{2 M}$ & $e_{2} e_{c} / h_{2 c}$ \\
\hline $\operatorname{Prob}\left(\mathrm{Q}_{12}\right)$ & & & 0.223 & 0.908 & 0.527 & 0.990 & 0.140 \\
\hline Cross-products & & & & $e_{3} e_{4} / h_{24}$ & $e_{3} e_{5} / h_{35}$ & $e_{3} e_{M} / h_{3 M}$ & $e_{3} e_{c} / h_{3 c}$ \\
\hline $\operatorname{Prob}\left(\mathrm{Q}_{12}\right)$ & & & & 0.166 & 0.178 & 0.971 & 0.754 \\
\hline Cross-products & & & & & $e_{4} e_{5} / h_{45}$ & $e_{4} e_{M} / h_{4 M}$ & $e_{4} e_{c} / h_{4 c}$ \\
\hline $\operatorname{Prob}\left(Q_{12}\right)$ & & & & & 0.960 & 0.991 & 0.963 \\
\hline 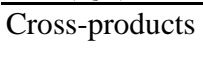 & & & & & & $e_{5} e_{M} / h_{5 M}$ & $e_{5} e_{c} / h_{5 c}$ \\
\hline $\operatorname{Prob}\left(\mathrm{Q}_{12}\right)$ & & & & & & 0.987 & 1.000 \\
\hline Cross-products & & & & & & & $e_{M} e_{c} / h_{M c}$ \\
\hline $\operatorname{Prob}\left(\mathrm{Q}_{12}\right)$ & & & & & & & 0.704 \\
\hline
\end{tabular}

Another interesting result is discovered by analyzing the trajectories of integration measures after the mid1990s. Our results show that the integration is a slow upward moving process that did not sharply rise towards full integration after the Euro was introduced even for the Euro countries. This is in contrast with the results presented by Hardouvelis et al (2005) and Fratzscher (2002), who find that many countries display integration measures close to full integration in magnitude, especially in the late 1990s. Our integration measure is based on the logistic function that ensures that estimated integration is no greater than 1 (full integration) and no less than 0 (full segmentation). Hence, it compares favorably with the measures used by both Hardouvelis et al (2005) and 
Fratzscher (2002), since those measures in theory and in some cases in practice are not restricted to [0,1] interval, and we were able to solve this problem. Our results are consistent with Harm (2001) and Wojcik (2002), who also present evidence suggesting lack of full market integration in European countries.

We plot the prices of European market and currency risks in Figure 2. As De Santis and Gerard (1998) note, the fitted risk prices are always plagued with the estimation error. To deal with his problem, we present estimated, Hodrick-Prescott (HP) filtered (see Hodrick and Prescott (1997)), and mean values of integration and risk price series. Inspection of the trajectories for both European risk prices reveals that their volatilities and magnitudes steadily decline over time, even though the currency risk price does not decline in magnitude and volatility as much as the market price of risk does. This result is consistent with theories of Errunza and Losq (1985) and Obstfeld (1994) and with empirical evidence presented in De Santis and Gerard (1998), Carrieri (2001), Adler and Qi (2003), De Santis et al (2003), and Carrieri et al. (2003).

Figure 1. Integration measures

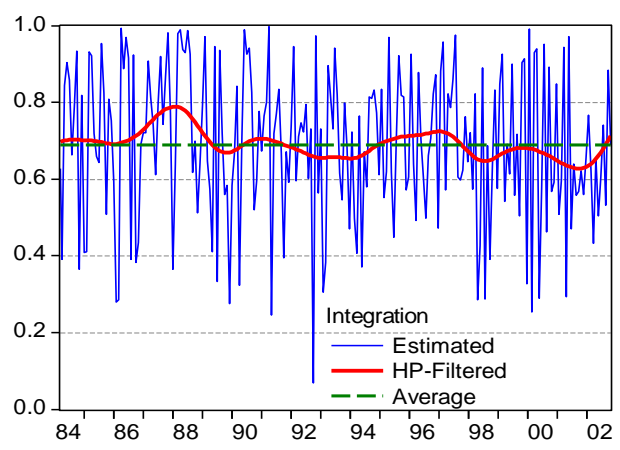

(a) France

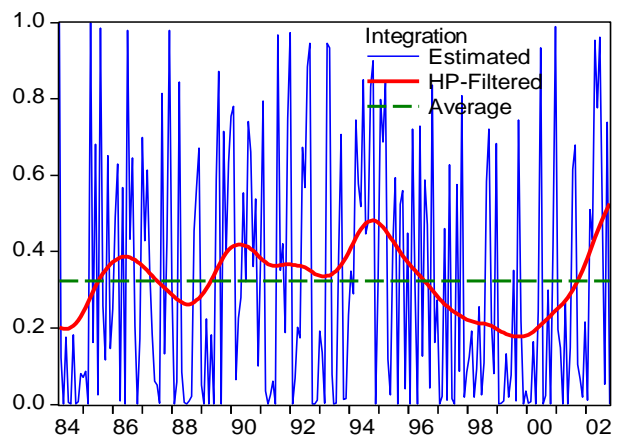

(c) Netherlands

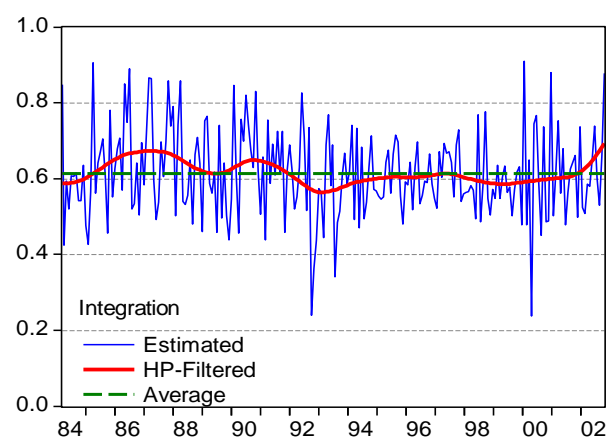

(b) Germany

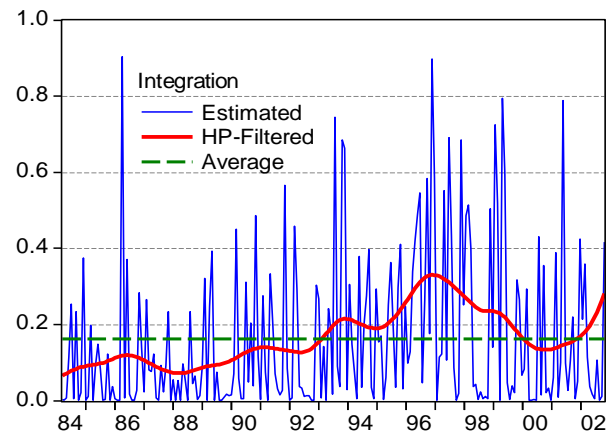

(d) United Kingdom

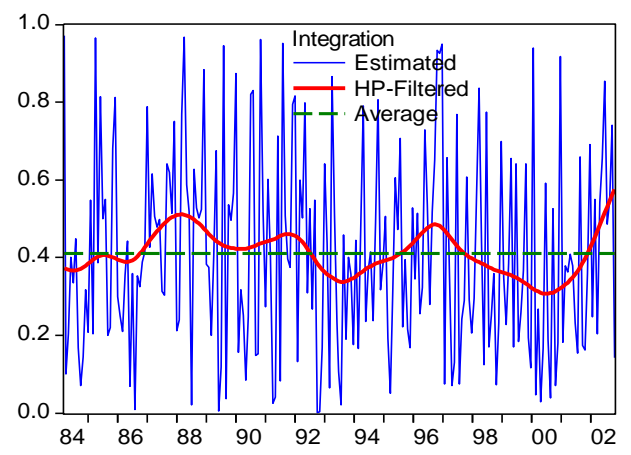

(e) Switzerland 
Figure 2. European prices of risk

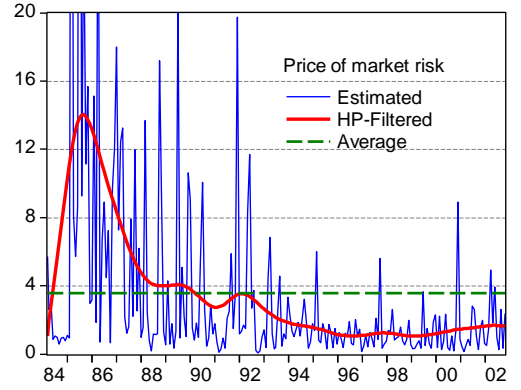

(a) Price of European market risk.

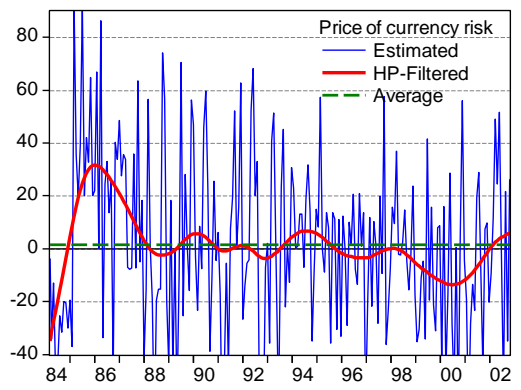

(b) Price of European currency risk.

Figure 3. Estimated local prices of market risk.

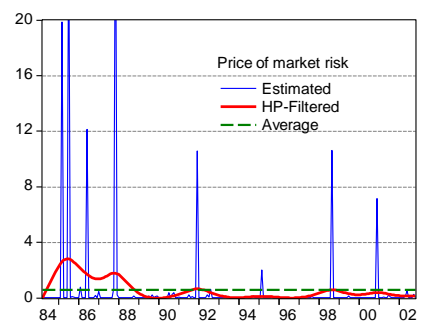

(a) France

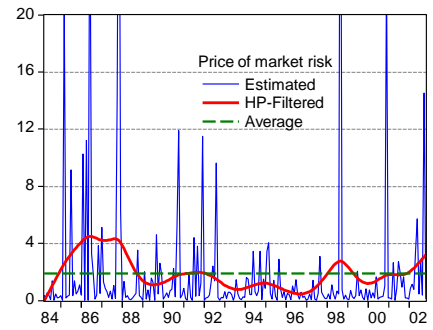

(b) Germany

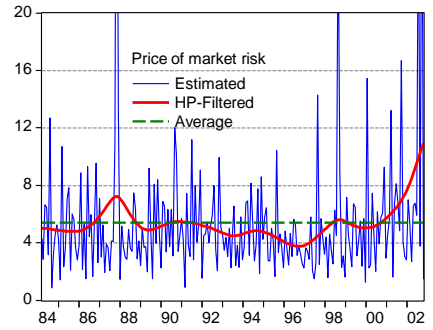

(c) Netherlands

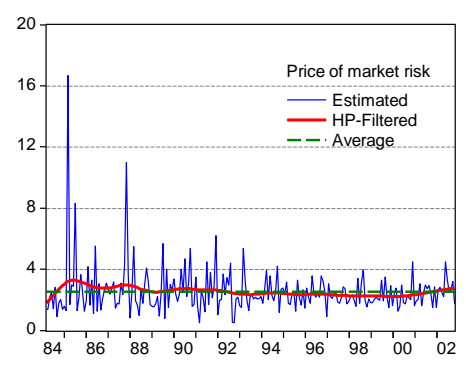

(d) United Kingdom

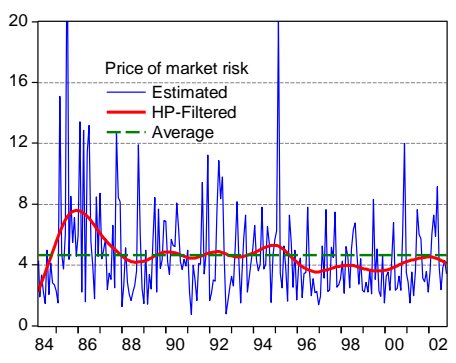

(e) Switzerland 
Figure 4. Estimated market and currency risk premia

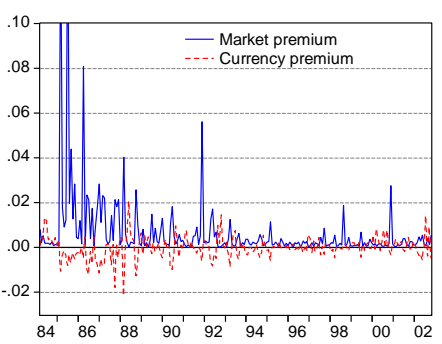

(a) France

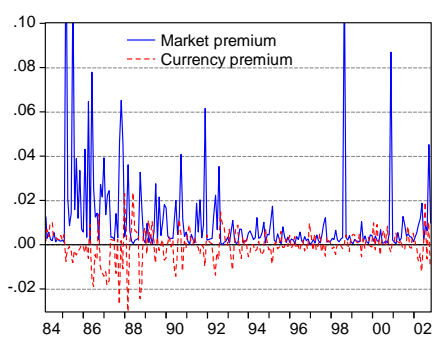

(b) Germany

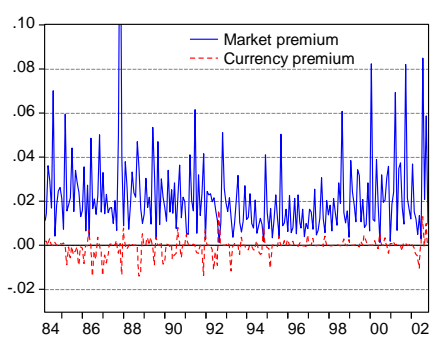

(c) Netherlands

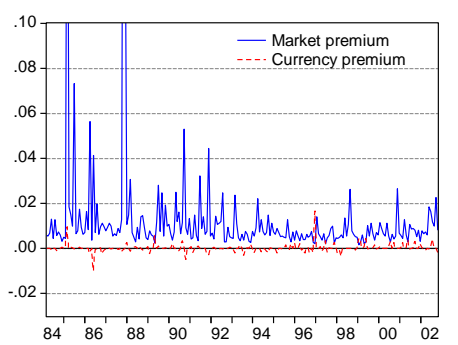

(d) UK

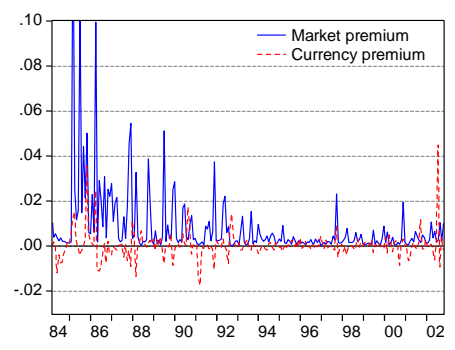

(f) Europe

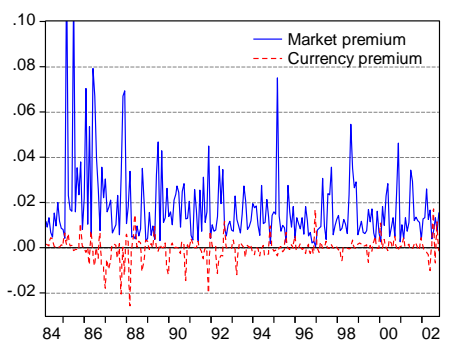

(e) Switzerland

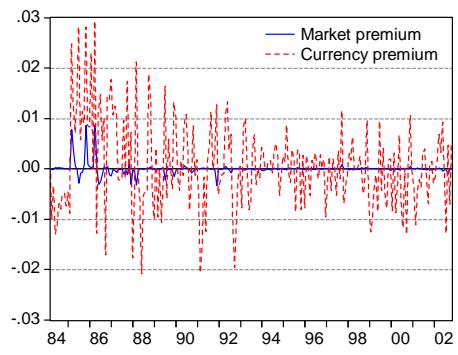

(g) Currency

The trajectories of prices for local market risk are presented in Figure 3. It appears that higher degree of capital market integration results in a lower market risk price, especially for large economies such as France and Germany. Finally, we present trajectories of the market and currency premia in Figure 4. The market premium is calculated by substituting estimated coefficients and series into the following equations:

$r_{i, t, \text { market }}=\varphi_{i, t-1} \delta_{M, t-1} \operatorname{cov}_{t-1}\left[r_{i, t}, r_{M, t}\right]+\left(1-\varphi_{i, t-1}\right) \delta_{i, m, t-1} \operatorname{var}_{t-1}\left[r_{i, t}\right], \quad i=1, \ldots, 5 \quad$ for $\quad$ all countries, $r_{M, t, m a r k e t}=\delta_{M, t-1} \operatorname{var}_{t-1}\left(r_{M, t}\right)$ for Europe, and $r_{c, t, \text { market }}=\delta_{M, t-1} \operatorname{cov}_{t-1}\left(r_{M}, r_{c}\right)$ for the currency index. The currency premium is calculated as $r_{i, t, c u r r e n c y}=\varphi_{i, t-1} \delta_{c, t-1} \operatorname{cov}_{t-1}\left[r_{i, t}, r_{c, t}\right], \quad i=1, \ldots .5$ for all countries, $r_{M, t, c u r r e n c y}=\delta_{c, t-1} \operatorname{cov}_{t-1}\left(r_{M}, r_{c}\right)$ for Europe, and $r_{c, t, c u r r e n c y}=\delta_{c, t-1} \operatorname{var}_{t-1}\left(r_{c, t}\right)$ for the currency index. These are parts of equations 4,5 , and 6 related to either market or currency risks. It is evident from Figure 4 that risk premia have a lot of turbulence in the mid-1980s, which eventually dies out towards the end of the 1990s. These results are in line with previous research; we hypothesize that the decline in risk premia occurred as a result of increased market integration and subsequent risk sharing (see Obstfeld (1994)). 


\section{CONCLUSION}

This paper examines time variation in equity pricing for European stock markets. We estimate this variation in the European and local prices of risks for a sample of three EMU and two non-EMU countries. We examine how risk premia of the countries that implemented the Euro differ from risk premia of the countries that kept their own currencies. In addition, we are able to identify when these changes took place.

Our analysis reveals that both market risk and currency risk are priced in the European marketplace. This finding is consistent with the IAPM of Adler and Dumas (1983) and empirical findings of other studies. The estimated European prices of market and currency risk have a period of large volatility in mid-1980s, but both volatility and magnitude of European prices of the two risks decreased with time.

Next, we find that estimated local market risk prices in countries that did not join the Euro system were higher than both the price of European market risk, and prices of market risk in countries that undertook currency unification. Our results are in line with predictions of the model offered by Bharma (2002), especially for large countries. We also find evidence consistent with Cooper and Kaplanis (1994) model that explains home bias in asset allocation. Overall, we document progress towards the European integration in financial markets of all countries in our sample.

\section{AUTHOR INFORMATION}

Dr. Usha Mittoo is the Bank of Montreal Professor in Finance at the I.H. Asper School of Business, the University of Manitoba. She received her Ph.D. in Finance from the University of British Columbia and joined the I.H. Asper School of Business in 1988. Dr. Mittoo is well known for her work in international capital markets and foreign listings.

Dr. Sergiy Rakhmayil is an Assistant Professor of Finance at Ted Rogers School of Management, Ryerson University. He received his Ph.D. in Finance from the University of Manitoba and joined Ryerson University in 2005. Dr. Rakhmayil specializes in asset pricing and international finance.

\section{REFERENCES}

1. Adler, M., and Dumas, B. (1983). "International Portfolio Choice and Corporation Finance: A Synthesis". Journal of Finance, 38, (3), 925-984.

2. Adler, M., and Qi, R. (2000). Mexico's integration in the North American capital market. Emerging Markets Review, 4, 91-120.

3. Bekaert, G., and Harvey, C. (1995). Time-Varying World Market Integration. Journal of Finance, 50, 403444.

4. Bharma, H. S. (2002). International Stock Market Integration: A Dynamic General Equilibrium Approach. London Business School working paper.

5. Carrieri, F. (2001). The effects of liberalization on market and currency risk in the European Union. European Financial Management, 7, 259-290.

6. Carrieri, F., Errunza, V., and Hogan, K. (2002). Characterizing world market integration through time. McGill University working paper.

7. Carrieri, F., Errunza, V., and Majerbi, B. (2003). Global price of foreign exchange risk and the local factor. McGill University working paper.

8. Cooper, I., and Kaplanis, E. (1994). Home Bias in Equity Portfolios, Inflation Hedging, and International Capital Market Equilibrium. Review of Financial Studies, 7, (1), 45-60.

9. De Santis, G., and Gerard, B. (1997). International asset pricing and portfolio diversification with timevarying risk. Journal of Finance, 52, (5), 1881-1912.

10. De Santis, G., and Gerard, B. (1998). How big is the premium for currency risk. Journal of Financial Economics, 49, 375-412.

11. De Santis, G., Gerard, B., and Hillion, P. (2003). The relevance of currency risk in the EMU. Journal of Economics and Business, 55, 427-462. 
12. Dumas, B., and Solnik, B. (1995). The world price of foreign exchange risk. Journal of Finance, 50, (2), 445-479.

13. Estrella, A., and Gikas A. Hardouvelis, G.A. (1991). The Term Structure as a Predictor of Real Economic Activity. The Journal of Finance, 46, (2), 555-576.

14. Errunza, V. and Losq, E. (1985). International asset pricing under mild segmentation: theory and test. Journal of Finance, 40, (1), 105-124.

15. Errunza, V., and Losq, E. (1989). Capital flow controls, international asset pricing, and investors' welfare: a multi-country framework. Journal of Finance, 44, (4), 1025-1037.

16. Errunza, V., Hogan, K., and Hung, M. (1999). Can the gains from international diversification be achieved without trading abroad? Journal of Finance, 54, (6), 2075-2107.

17. Fedorov, P., and Sarkissian, S. (2000). Cross-sectional variations in the degree of global integration: the case of Russian equities. Journal of International Financial Markets, Institutions and Money, 10, 131-150.

18. Fratzscher, M. (2002). Financial market integration in Europe: on the effects of EMU on stock markets. International Journal of Finance \& Economics, 7, (3), 165-173.

19. Gultekin, M. N., Gultekin, N. B., and Penati, A. (1989). Capital controls and international capital market segmentation: the evidence from the Japanese and American stock markets. Journal of Finance, 44, 849869.

20. Hardouvelis, G. A., Malliaropulos, D., and Priestley, R. (2005). EMU and European stock market integration, Journal of Business, forthcoming.

21. Harm, C. (2001). European financial market integration: the case of private sector bonds and syndicate loans. Journal of International Financial Markets, Institutions and Money, 11, 245-263.

22. Hebbink, G. and Peeters, M. (1999). The circulation of Euro banknotes and coins in the Netherlands. De Economist, 147, (1), 73-83.

23. Honig, H. (1996). The guilder in the run-up to Emu. Corporate Finance, 5-8.

24. Karolyi, G. A., and Stulz, R. M. (1996). Why do markets move together? An investigation of US - Japan stock return comovements. Journal of Finance, 51, (3), 951-986.

25. Karolyi, G. A., (2003). The Role of ADRs in the Development and Integration of Emerging Equity Markets. Ohio State University working paper.

26. Obstfeld, M. (1994). Risk-taking, global diversification, and growth. American Economic Review, 84, (5), 1310-1329.

27. Sentana, E. (2002). Did the EMU reduce the cost of capital? The Economic Journal, 112, 786-809.

28. Solnik, B., and McLeavey, D. (2002). International Investments, 5th ed. (New York: Addison-Wesley).

29. Wijffels, H. (1997). Dutch take courage from experience. The Banker, 147, (853), 14-16.

30. Wojcik, D. (2002). Cross-border corporate ownership and capital market integration in Europe: Evidence from portfolio and industrial holdings. Journal of Economic Geography, 2, (4), 455-461. 